BANCO DE ESPAÑA

\title{
REGIONAL MIGRATION IN SPAIN: THE EFFECT OF PERSONAL CHARACTERISTICS AND OF UNEMPLOYMENT, WAGE AND HOUSE PRICE DIFFERENTIALS USING POOLED CROSS-SECTION
}

Pablo Antolín and Olympia Bover 
BANCO DE ESPAÑA

\section{REGIONAL MIGRATION IN SPAIN: THE EFFECT OF PERSONAL CHARACTERISTICS AND OF UNEMPLOYMENT, WAGE AND HOUSE PRICE DIFFERENTIALS USING POOLED CROSS-SECTIONS}

Pablo Antolin* and Olympia Bover**

(*) Nuffield College, Oxford

$(* *)$ Banco de España

We are grateful to Manuel Arellano and John Muellbauer for very helpful discussions. This paper has also benefited from comments and suggestions by Samuel Bentolila, José María Bonilla, Chris Gilbert, Juan F. Jimeno, Pilar L'Hotellerie, Richard Spady and participants at the Banco de España workshop and the Nuffield Econometrics Seminar. Financial support for Pablo Antolín from the "Fondo del Banco de España para la Financiación de Estudios sobre Mercado de Trabajo" and the Spanish Ministry of Educations is gratefully acknowledged. 
In publishing this series the Banco de España seeks to disseminate studies of interest that will help acquaint readers better with the Spanish economy.

The analyses, opinions and findings of these papers represent the views of their authors; they are not necessarily those of the Banco de España.

ISBN: 84-7793-235-2

Depósito legal: M-19530-1993

Imprenta del Banco de España 


\section{INTRODUCTION}

During the $80^{\prime}$ 's Spain experienced a remarkable reversal of inter-regional migration flows. The traditionally poor and net outmigration regions (Andalucia, Castilla-León, Castilla La Mancha and Extremadura) became net immigration ones and the reverse happened for rich regions (like Cataluña, Comunidad Valenciana, Madrid and the Pais Vasco). The first signs of this change appeared in the first half of the decade (in Andalucia, Cataluña and the Pais Vasco) and were reported by Olano (1990). During the second half of the 80's the reversal was generalised. In Table 1 we report the regional migration flows from a representative sample of adult men in the labour force, covering the period 1987-1991. The percentage of outmigrants from Cataluña more than doubled the percentage of immigrants, while in Madrid it was almost ten times as big. In Andalucía, and particularly in Extremadura and Castilla La Mancha, the situation was the opposite.

Indeed, what is important is not the aggregate decroase in interregional mobility since the early 70's (which has remained stagnant) but the change in the pattern of inter-regional migration. What is it then that makes people stay in or move from regions in Spain at present? Why did people stop migrating from the poorest regions and, on the contrary, start to do so from the better-off ones? We think it is important to identify the factors behind individuals' migration decisions. Knowledge of these factors will be specially relevant for analysing the housing and labour markets in Spain.

The purpose of this paper is to identify which regional economic factors influence the individual's migration decision, taking into account personal characteristics. We use individual data from the Migration Survey, included in the Spanish Labour Force Survey ("Encuesta de Población Activa"), pooling independent cross-sections from 1987 to 1991. The availability of micro data will allow us to measure life-cycle and family factors that influence migration decisions. In doing this, we control for different individual propensities to migrate so as to be able to assess the genuine impact of regional economic factors (see Greenwood (1985)). We expect that the rich cross-sectional variation available (individual and 
regional) will allow us to disentangle regional effects from personal factors. Pissarides and Wadsworth (1989) use a single cross-section to assess the effect of personal versus regional unemployment in the UK. We allow for the effect of regional variables to vary across people according to their personal characteristics, i.e. we allow the effects of regional variables to differ across subpopulations defined by personal characteristics. One contribution of the paper is to show that personal characteristics not only have an important direct effect on the migration decision, but that they also alter the effect on such decision of the regional economic variables and affect the interpretation of these regional effects. Many migration studies report a lack of significance of area economic variables (in particular unemployment) in explaining migration (Pissarides and Wadsworth (1989), Greenwood (1975, 1985)). DaVanzo (1978) finds, for the US, that unemployment is relevant only for unemployed persons. We go a step further and consider a richer array of personal characteristics interacting with regional variables, and this proves to be the key to making sense of the regional unemployment rate effect.

The paper is organised as follows. In Section II we describe our framework of analysis and the data. The results are presented and discussed in Section III. In Section IV we report some misspecification tests to check the robustness of the results. Section $V$ states the conclusions. 


\section{FRAMEWORK OF ANALYSIS AND DATA}

The purpose of this work is to study the factors that influence the individual's probability of migrating. The relevant migration literature has pointed out the existence of push factors to move, those which influence movement from the place of origin, as well as pull factors, those which influence movement to a particular place. Place-to-place type models of migration consider the conditions at source as well as those at destination. Here we do not consider a place-to-place model because of insufficient information in our data ${ }^{1}$. Indeed, in our sample of 224,714 individuals (obtained by pooling five years of the Migration Survey) there are only 664 inter-regional migrants. This would not be enough to identify the factors in a place-to-place model involving the 17 Spanish regions. We therefore focus on the regional push factors (as compared to the national average) that make people migrate (or prevent them from doing so), taking into account their different propensities to migrate according to personal characteristics.

In terms of the standard human capital or random utility framework, potential migrants would evaluate the present discounted expected costs and returns of moving and staying. They will choose the option that produces the higher net expected return ${ }^{2}$.

Let $d_{1}^{*}$ represent the expected difference between the utility of migrating and the utility of staying given observed regional and national economic variables $\left(R_{1}, R_{n}\right)$ as well as other variables in the information set of individual $i$. We specify $d_{1}^{*}$ as follows

$$
\mathrm{d}_{1}^{*}=\mu_{0}\left(\mathrm{X}_{1}\right)+\mu_{1}\left(\mathrm{X}_{1}\right)\left(\mathrm{R}_{1}-\mathrm{R}_{\mathrm{n}}\right)+\mu_{2}\left(\mathrm{X}_{1}\right) \mathrm{R}_{\mathrm{n}}+\xi_{1} \quad \mathrm{i}=1, \ldots, \mathrm{N}
$$

where $\mathrm{X}_{1}$ denotes a vector of individual characteristics and $\xi_{1}$ is a disturbance term that includes unobserved variables.

The individual will migrate if $d_{1}^{*}>0$, and the probability of this event conditional on $R_{1}, R_{n}$ and $X$ can be written as 


$$
\begin{aligned}
& \operatorname{Prob}\left(d_{1}^{*}>0\right) \\
= & \operatorname{Prob}\left(\mu_{o 1}+\mu_{11}\left(R_{1}-R_{n}\right)+\mu_{21} R_{n}+\xi_{1}>0\right) \\
= & F\left(\mu_{o 1}+\mu_{11}\left(R_{1}-R_{n}\right)+\mu_{21} R_{n}\right)
\end{aligned}
$$

where $F$ is the cumulative distribution function of $-\xi_{1}$ and

$$
\mu_{\mathrm{k} 1}=\mu_{\mathrm{k}}\left(\mathrm{X}_{1}\right)=\mu_{\mathrm{ko}}+\mu_{\mathrm{k} 1} \mathrm{X}_{1} \quad \mathrm{k}=0,1,2
$$

In our empirical model we also allow for the possibility of asymmetric effects for the regional economic variables between abovenational-average and below-national-average regions. The way we introduce this non-linearity is by specifying the effect of an economic variable $r$ as $b_{1}\left(r_{1}-r_{n}\right)+b_{2}\left|r_{1}-r_{n}\right|$, so that for regions where $r$ is above the national average, the total effect of $\left(r_{1}-r_{n}\right)$ is $b_{1}+b_{2}$ and for regions where $r_{1}<r_{n}$, the total effect of $\left(r_{1}-r_{n}\right)$ is $b_{1}-b_{2}$.

The data used come from the Spanish Migration Survey ("Encuesta de Migraciones") which is part of the Labour Force Survey ("Encuesta de Población Activa" (EPA)) conducted by the Instituto Nacional de Estadística (INE-the Spanish National Statistics Office). The EPA is conducted on all members of around 60,000 households (approximately 200,000 persons) each quarter. Every second quarter of the year some questions concerning the individual's situation one year prior to the interview have to be answered as part of the EPA. The questions relate to the region of residence, the situation with respect to the labour market, the source of earnings and the economic sector, all these referred to the $2^{\text {nd }}$ quarter of the previous year. In our study an individual is considered as having migrated if his current region of residence differs from the one he had the previous year.

The Migration Survey started in its current form in 1987. We have five cross-sections of data, corresponding to the surveys from 1987 to 1991 , which we pool together. The pooling is crucial given the low proportion of inter-regional migrants in Spain. We only have 664 migrants in our sample for these years, who account for $0.295 \%$ of the total of 
224,714 individuals. It is interesting to compare this to the UK where, for a single cross-section from the British Labour Force of 1984, Pissarides and Wadsworth (1989) report $1.12 \%$ of migrants in their sample, which is almost four times ours. In theory, pooling would allow us to study the effect of general economic conditions (national aggregate economic variables) that may influence migration decisions. For example, the probability of migration may be lower at higher overall unemployment rates (Pissarides and Wadsworth (1989)). However, we only have five years of data and this is not much to assess the impact of business cycle variables. We will, however, pursue these considerations in the next section.

Our sample includes men, aged 16 to 70, who are in the labour force both at the time of the survey and a year before. The sample is also confined to Spanish citizens not living abroad at the time of the survey or in the previous year (those in the North African enclaves of Ceuta and Melilla are not included either) ${ }^{3}$. We exclude women because their migration behaviour could be quite different from that of men. Married women in particular "are more likely to be tied movers", quoting Mincer (1978). Men who are not household heads are included because it is important to assess whether the family ties of people living with parents or relatives affect their migration behaviour.

It is important to distinguish between variables defined at the time of the survey and those defined one year earlier. When studying the determinants of migration we have to use mainly information about the individual's situation a year earlier (i.e. before moving), otherwise possible consequences of migration are likely to be confused with causes of migration. We do assume however that the household structure (marital status and children) is exogenous in the sense of not being influenced by migration decisions.

With respect to the general economic variables used, we have to take into account that the survey is about migration decisions over the past 12 months and that when people make their migration decision, they use prior economic indicators in assessing their choice. Therefore, we use 
macroeconomic variables that are averages of the values over the year ending in the second quarter of the year before the survey.

In the Data Appendix, we report detailed information about the construction of the variables used in this work. We also provide Tables with information on the data, both about our sample of individuals from the EPA and about the general economic variables. Figures showing the evolution of the regional differentials of the economic variables are also provided. 


\section{RESULTS}

Our final results, corresponding to the maximum likelihood estimation of (1) assuming a logistic distribution for $F$, are presented in column 1 of Table $2^{4}$. Another informative way of highlighting the effects of different factors on the probability of migration is by calculating the implicit predicted probabilities for some individual types and seeing how these probabilities change when various factors change. We report the result of this exercise (based on the estimates of column 1) in Table 3.

\section{Estimated effects of personal characteristics}

We begin by considering the direct effects of the person's characteristics $^{5}$ on the probability of migration. They all have the expected sign. The probability of migration is higher for young people, particularly for those aged 25 to 34 , and is much lower for the over 50's. Higher education increases the probability of migration and people with primary education are the less prone to migrate. The probabilities estimated in Table 3 show that having higher education more than doubles the probability of migration. The dummies describing the family structure are very interesting. Aside from the strong negative effect of children ${ }^{6}$ on the probability of migrating, we obtain an even stronger negative effect if the person is single and not head of a household. This confirms Mincer's hypothesis of very low migration rates for single people living with parents or relatives. This may be particularly important in Spain where family bonds are strong. Another very significant "tie" that diminishes the probability of migration is to have a working wife. This may be of some relevance for explaining part of the decrease in migration over time given the increase in the female participation rate.

Let us now examine the effect of the individual's own employment situation. The unemployed not registered at the official employment of fice have the highest probability of migrating in the next twelve months. Employed persons come next. However, being a registered unemployed person significantly reduces the probability of migreting other things being equal. From Table 3 (last two columns), the probability of migrating for a person not registered as unemployed is more than four times greater 
than for a person registered as unemployed. As can be seen in the Data Appendix, the registration dummy can be quite safely taken to capture an important portion of the people registered in the $2^{\text {nd }}$ quarter of the year prior to the twelve-month period where the migration decision is observed. Why do registered people tend to migrate less? One possibility is to attribute this situation to unemployment benefits, since registration is a necessary condition for receiving benefits and the official register is not seen to perform well as an employment agency. Benefits may reduce the incentive to migrate in search of a job. Furthermore, it is often the case that individuals alternate periods of employment with periods of unemployment with benefits and expectations of getting the same kind of job again, on an on-off basis. Examples can readily be found in agriculture, the canning industry and tourism-related activities. However, we do not have enough information in our data to confirm the benefit hypothesis because we do not know whether the individual was receiving benefits the previous year. Another possible factor would be that, as a consequence of moving to a different region in search of work, the individual may lose his order on the Official Employment List. Indeed, if the individual registers in his new region Official Employment Office in the first two weeks after moving, he does not lose his seniority rights but the order on the new list will probably be different. The importance of the registration variable can be seen by looking at the results if it not included (Table 4 column 1). In this case, being unemployed does not affect significantly the probability of migration; that is, being unemployed or employed appears to be irrelevant for the migration decision. It is only when the registration variable is included (column 2 Table 4) that we are able to disentangle two significant effects of the opposite sign: a positive effect for the unregistered unemployed, and a negative one for the registered unemployed. Among employed people, employees tend to migrate more than the self-employed, particularly employees in the public sector. This higher mobility of civil servants is natural, given that they move with jobs. It should also be added that during our sample period an important process of administrative decentralisation has taken place. Being over three years in the job reduces migration. As for the probability of migration according to economic sector, people in construction are more mobile, followed, in that order, by services, agriculture and industry ${ }^{7}$. 
As a measure of the importance of the individual characteristics, it is useful to know that the percentage of concordant pairs for a model where only our chosen personal characteristics are included, but not regional variables, is $69.6 \%$.

\section{Estimated effects of regional economic variables}

Let us now examine the effect of the economic conditions in the region of origin (as compared to the national average) on the probability of migration. The only (observable) factors that turn out to be influential, in one way or another, are the following: unemployment rate differentials, differentials in the growth of the participation rate, real house price differentials and real wage differentials.

We will first discuss the effect of unemployment rate differentials. To be able to make sense of the effect of regional unemployment, it is essential to take into account the particular situation of each individual. On its own, the regional unemployment differential has a strong, wrong-signed (negative) effect (see column 2 Table 4); that is, people from regions with an unemployment rate above the national average would have a lower probability of migrating. Da Vanzo (1978) has shown, for the US, that interacting regional unemployment with an unemployed person dummy gives significant and correctly signed results. In our case this did not solve the puzzle (see Table 4 column 3) (nor did it for Pissarides and Wadsworth (1989)). In view of the result, we tried potentially omitted variables like the differentials in the rate of change of the unemployment rate, in the rate of change of employment, in vacancy rates or in labour market tightness. We also tried disaggregating by economic sector the regional unemployment rate differentials and the above-mentioned variables. Disaggregated regional unemployment produces astonishingly similar results. None of the other potentially omitted variables (aggregated or disaggregated) changed our results either. We had to take into account a rich range of the person's characteristics to obtain reasonable results. Here, the introduction of the registered dummy is significant as well (see Table 4 column 4 ). The results in Table 2 column 1 indicate that the effect on the probability of 
migration of the regional unemployment differential will vary in the following way $^{\theta}$ :

Effect of Regional Unemployment Differential=

(4.19* higher education $+3.62 *$ unemployed $-13.81 *$ registered at Employment Office -8.32 * single not head of household -5.13 * children) * Regional Unemployment Rate Differential.

This shows that higher-than-average regional unemployment will barely induce people to migrate if they are unemployed, but not if they are registered. In principle, this would also imply that the registered unemployed would have a higher probability of migrating than the unregistered unemployed, when they are in lower-than-average unemployment rate regions. We introduced the possibility of an asymmetric effect, i.e. different effects for registered people in lowerthan-average unemployment regions and for those in the above-average ones. The effect was significant and of the expected sign (i.e. positive for low unemployment regions). This means that registered people have a lower probability of migrating both in higher- and in lower-thanaverage regions. However, when this extra effect is allowed for, the additive effect of registration in employment offices diminishes and loses significance although the total effect of registration remains significant and strong. The fit seems to be slightly worse as well. In any case it is difficult to distinguish between these two very similar models. The total effect of being registered in our reported model is $(-1.48-13.81$ * Unemployment Rate Differential). In our data, the region with the lowest unemployment rate has an unemployment rate differential of -0.09 and hence the total effect would never be positive for our sample.

One might think that the effect of registration is the result of the existence of a special benefit in Andalucia and Extremadura for the unemployed in agriculture. We tried the effect (both additively and interacted) of a dummy for people unemployed in agriculture (last year) living in Andalucia or Extremadura. This variable works in the same direction as the registration dummy but it is significant only if added either additively or interactively and it is in any case not as significant 
as the registration variable. We have also introduced both the special benefit dummy and the registration dummy (the latter modified to exclude people on the special agriculture benefit). We cannot reject that both coefficients are the same (this is valid if both variables are introduced either additively or interactively). Therefore, registered people in other regions and other occupations that are also included in the broader registration variable do matter and behave in the same way, reinforcing the effect.

Having higher education will influence in the expected direction. The presence of children (or living with relatives) will reduce the probability of migration for people in high unemployment regions. On the other hand, from the results in column 4, Table 4, the regional unemployment differential does not seem to influence significantly the decision of employed people (except for the employed with higher education, children or living with relatives). One possible reason (among others) may be that employed people that migrate do so with jobs (but we cannot confirm this without a model where migration and current employment status were jointly determined). Employed people with children have a higher probability of moving from a lower than average unemployment region; this may reflect people seeking to improve their quality of life because of the children (we shall talk more about this factor in what follows).

One important conclusion here is that regional unemployment will have a completely different influence on individuals depending on their family and employment situation. This makes perfect sense and highlights the overwhelming importance of individual characteristics and the need to take into account microdata information in studying migration behaviour. Personal characteristics not only have a direct, independent effect, but are also important in explaining the influence of local conditions.

We now turn to the effect of differentials in the rate of change of the participation rate. It seemed important to take into account this variable (together with the unemployment rate) given the changes in the participation rate during the 80 's in Spain. It proved to be significant. People in regions with an above-average increase in participation are more 
likely to migrate. This may reflect participation growth driving away people because they face more difficulties in finding a job. Our evidence points slightly towards higher education tending to cancel out the positive effect of the regional participation growth. This influence of education is weak but goes in the expected direction, with people with a higher education having better job opportunities and information. We report it as a further illustration of the potential importance of personel characteristics in order to explain the effect of regional conditions.

House price differentials are one of the most important elements in cost-of-living variations ${ }^{9}$. In the second half of the 80 's Spain experienced substantial house price increases in some regions. It is interesting to see in which sense these important variations may have influenced the pattern of migrations between regions. In the EPA there is no information about the individual's housing tenure. We use regional differentials in the price of owner-occupied housing. Owner occupation in Spain is very high (around 828 ) and includes subsidised housing. It would also be desirable to study the effect of regional rented housing prices; however, there are no meaningful data on prevailing rents in Spain. At this point it should be noted that since we are studying the probability of migrating in general (i.e. of leaving a region without consideration of the destination) here we will be able to capture only the influence of house prices in the region of origin. Without a place-to-place model we cannot capture the "attraction" or "disincentive" effect of house prices prevailing in destination regions.

Given that housing expenditure on owner-occupied housing is not only a consumption decision but also an investment one, we allowed for an asymmetric effect of house price differentials between higher- and lower-than-average-house-price regions (column 1, Table 2). The difference is significant and as a result the coefficient for higher-thanaverage-house-price regions is $2.154(=0.675+1.479)$ and for lower-thanaverage is $-0.804(=0.675-1.479)^{10}$. This shows that people in regions with higher-than-average house prices have a strong incentive to migrate. We will discuss later how we think this ties up with the other observed factors to explain the current pattern of regional migration. Low regional house prices also induce people to migrate but the effect is much 
smaller than the previous one and may be due to low house prices capturing other undesirable characteristics of the region.

Finally, let us look at the estimated effects of real wage differentials. This variable has the opposite sign to what we would have expected if we believe wage differentials correct disequilibrium by encouraging migration from low wage regions. However, no asymmetries, potentially observed omitted variables or personal characteristics interactions proved significant. People tend to leave from high real wage regions. There are several possible explanations. The first one would be that the regional wage is an overly aggregated measure to be relevant to the individual. We are not able to disaggregate in any way since regional wages by economic sector are not available for this period. Along the same lines it is possible that a significant proportion of employed people tend to leave high wage regions in search of better prospects for promotion. We could not identify such an effect given the scarce information on the employment status of the individual prior to the migration decision. For example, the professional status at the time is not available for a potentially meaningful interaction. Another appealing explanation is the quality-of-life motive, that is, people leaving high wage regions because of an increased demand (once a certain level of income is reached) for better quality of life (see Greenwood (1985)). Regional wage differentials could then be seen as compensating differentials (see Roback (1982)).

People leaving from regions with high house prices and high wages might reflect return migrations of individuals having originally migrated from the poor region of origin in the 60's and 70's. However, we tried interactions of some individual variables that would capture this situation like age near retirement, and they do not help to explain this effect. Specifically, it is not the case in our sample that retiring people are those who leave the more prosperous regions. Another possibility we have explored is that many of the people who leave, for example, Madrid, have simply changed their residence and commute to work to Madrid. However, only $4.5 \%$ of the individuals migrating from Madrid live in the contiguous regions of Castilla-León and Castilla La Mancha and declare themselves to be working in Madrid ${ }^{11}$. 
From the estimated regional effects and their interactions with individual characteristics, we can see that the reasons that make people at present migrate to another region in Spain are different from the reasons that made people move in the 60's and 70's. People that move now seem to do so in search of cheaper housing, better quality of life and perhaps professional promotion. High regional unemployment or own unemployment no longer trigger substantial migrations from people in poor regions. Unemployment will only increase the probability of migration if the individual has higher education, or is unemployed and not registered as such. These factors seem to be behind the observed facts that people are leaving regions like Madrid, Cataluna or the Pais Vasco and staying in (and even moving to) regions like Andalucia or Extremadura.

\section{Potential effects of national aggregate economic variables}

With this data set we could also try to study the effect of aggregate economic variables. Indeed, since we are pooling five crosssections of the EPA (corresponding to the $2^{\text {nd }}$ quarters of five years) we could exploit the time variation, aside from the rich cross-section (individual and regional) variation, to see whether variables like the national unemployment rate affect the individual's migration decision, i.e. to what extent national economic variables affect the individual's decision beyond his own status and his region's economy. However, we are reluctant to do so because with such a short period (i) we cannot really include at the same time all the variables that one would reasonably think of to properly specify the model; and (ii) we could just be capturing the correlation present in the short period available. For example, on its own, the rate of change of the unemployment rate is significant, with an estimated coefficient of 2.21 ( $t$-ratio=2.78). This (counter-intuitive) positive sign may just be picking up the fact that for the period 19871991, unemployment (and the rate of change of unemployment) has been mainly declining, as has migration. However, we are also able to identify a significantly negative interaction of the unemployment change with the registered unemployed dummy $(-9.85, t$-ratio $=2.05)$. In this case again (very much as for regional unemployment), the national unemployment change effect corresponding to the unregistered unemployed is barely significant (3.44, t-ratio $=1.49$ ) and is completely insignificant for the 
employed $(-1.04, t-r a t i o=0.42)$. This would imply that growing national unemployment may not affect the individual's migration decision, except if the person is registered as unemployed. In this case, growing unemployment at the national level will diminish even further the person's probability of migrating. On the same lines, the only other aggregate variable that proved significant was the rate of change of employment, with a negative coefficient. Interestingly, if we also introduce the percentage of people with temporary contracts, both variables are jointly (but not individually) significant with negative coefficients. It is difficult to distinguish which part of the negative effect is due to employment growth (people migrating less because employment prospects in general improve) and which part is due to the fact that part of this employment growth is achieved by temporary contracts (people migrate less because temporary contracts are less attractive and not worth moving for).

In any case, with our sample period, we cannot be assertive as to the role of national aggregate variables. However an important point is that their inclusion does not alter the results on the effects of the individual and regional variables (more on this point below). 


\section{MISSPECIFICATION ANALYSIS}

Once we obtained a satisfactory logit model, we subjected it to some misspecification tests.

(i) We added to our chosen specification time dummies that will allow for all possible aggregate time varying effects. This did not affect in any way our estimated regional effects (see Table 2 column 3 ) that do vary over time; these truly reflect cross-sectional regional differences. The percentage of concordant pairs increased by 0.2 only. Furthermore, we have estimated a model replacing all our regional variables (and their interactions) by sixteen regional dummies and four time dummies. The increase in our measure of predictive power was only 0.18 (reaching 73.78). The diference in predictive power $(0.1 \%)$ with the previous model (our chosen model with four added time dummies) reflects (as a lower bound) that interactions of regional variables with individual characteristics are not only important for the interpretation of the estimated effects of the regional variables but also contribute to increase the predictive power. If only the sixteen regional dummies are included, the percentage of concordant pairs is 73.48 . Hence our model does well as far as predictive power is concerned, compared to heavily parameterised models with dummies. The advantage of our specification as far as economic interpretation is concerned is obvious.

We also explored the possibility that our estimated regional effects (in particular the wage and house price differentials) are picking up spurious correlation due to time variation of the regional differentials by adding to our model sixteen regional dummies and aggregate variables. The results confirm that the regional effects we capture are indeed genuine.

(ii) We estimated the model assuming a normal rather than a logistic distribution fuction (Table 2, column 2). The estimated effects with the probit model are very similar to the ones with the logit ${ }^{12}$. To test whether one of the two models fits the data better than the other we performed a likelihood ratio-type test for non-nested hypotheses applying the method proposed by Vuong (1989). The test statistic is as follows: 


$$
L R V=\frac{\hat{\mathrm{L}}_{\text {prob1t }}-\hat{\mathrm{L}}_{\text {logit }}}{\sqrt{\sum \hat{\mathrm{m}}_{1}^{2}-\frac{1}{N}\left(\hat{\mathrm{L}}_{\text {prob1t }}-\hat{\mathrm{L}}_{\text {log1t }}\right)^{2}}}
$$

where $\quad \hat{m}_{1}=i_{(\text {probit }) 1}-\hat{i}_{(10 \text { ogit }) 1}$,

I represents the maximised log-likelihood,

$\hat{i}_{1}$ represents the estimated log-likelihood for each observation, and $\mathbf{N}$ is the sample size.

Under the null hypothesis that the two models fit the data equally well, LRV has a distribution $N(0,1)$ in large samples. In our case $L R V=-1.51$, hence we cannot discriminate between the two competing models given the data.

Aside from comparing the logit model with the probit model which is the obvious parametric alternative, we considered a test against a more general semi-parametric binary model where the density function is estimated. However, an estimation procedure such as that proposed by Klein and Spady (1993) is not readily available in our case because of the very large number of observations involved ${ }^{13}$.

(iii) Another way to test our specification is to split the sample in subsamples and perform a likelihood ratio test comparing the restricted model estimated from the complete sample with the unrestricted model estimated from the subsamples. Notice that given the small number of migrants we can split the sample into two at the most. We try to break the sample in such a way as to obtain two subsamples where one of them has clearly a higher mean probability of migration (but at the same time the two subsamples should have a sufficient number of migrants). In this way we would check whether estimating the model using different probability ranges does change the results. We performed two different sample stratifications.

First, we split the sample by age, into one subsample with the people aged 25-34 which is the age group most prone to migration $(0.56 \%$ 
observed migrants), and another with the rest $(0.218$ observed migrants). We have 319 migrants in the first subsample and 345 in the second. This produces a likelihood ratio test of 16.7 with 23 degrees of freedom which easily accepts that the estimated models are equivalent ${ }^{14}$.

Second, we split the sample according to head of household status. In the first subsample we have the head of household (with 369 migrants, representing 0.248 of the subsample) and in the second the non head of household, with a higher migration frequency (and 295 migrants representing 0.418 of the subsample). In this case the LR test is 22.14 with 20 degrees of freedom which would not reject the null hypothesis at any reasonable significance level. Furthermore, account should be taken of the very high number of observations and the fact that if we estimated the restricted models dropping all the insignificant variables (their effect probably cannot be well identified given the number of migrants in the subsamples) the number of degrees of freedom would increase (by more than ten) and $H_{1}$ would be even more clearly rejected ${ }^{15}$.

We therefore believe that the results we present in Table 2 column 1 are reasonably robust. 


\section{FURTHER COMMENTS AND CONCLUSIONS}

This paper presents evidence on the importance for the migration decision in Spain of the person's situation, in particular:

(i) family characteristics, such as being married to a working woman, having children, or living with relatives

(ii) personal factors such as education or age and

(iii) own employment situation such as being registered as unemployed as opposed to non-registered, or being self-employed.

The paper also studies the influence of regional economic variables and reveals that interactions between these and personal characteristics are crucial for explaining the current pattern of regional migration flows in Spain. Personal characteristics not only have an important direct effect on migrations but they also alter the effect of some regional economic variables on the migration decision and affect the interpretation of these regional effects. The findings about the effects of the regional variables described in the previous section help us explain the present pattern of inter-regional migration in Spain. In the first place, individuals, due to their family situation and more importantly, due to the register system, do not respond to their own unemployment nor to high unemployment in their regions by migrating. This explains why people from high unemployment regions like Andalucia or Extremadura do not move to more prosperous regions, as they used to do in the 60's and up to the mid 70's. Second, the people that move are from regions where house prices and wages are higher than average and hence they probably move in search of cheaper housing, better quality of life and professional promotion. People leave from regions like Madrid and Cataluña. These moves do not seem to be return migrations because they do not affect particularly people near retirement age. Hence, the important point is that the people that move are not the same kind of people that used to do so; the reasons behind migration decisions in Spain have changed. Whether this is a desirable situation or not depends on the state of the regional labour markets. The appreciation of this situation will be different if, for example, Madrid's labour market needs people (of the kind who are leaving, or of the kind that are failing to come) or if, on the 
contrary, it is facing "saturation" and the direction of the current flows might encourage development in the traditionally poorer regions. But that is another story. 


\section{Data Appendix}

\section{Individual Charecteristics dummies}

Source: Labour Force Surveys ("Encuesta de Poblacion Activa") from 1987 to 1991 ( $2^{\text {nd }}$ quarters), provided by the "Instituto Nacional de Estadistica" (INE-National Statistics Office).

Migration. The migration survey provides the place of residence one year prior to the sampling (if different from current one) and the current province of residence). We group the provinces in the standard 17 regions or "Comunidades Autónomas", and define migration as a change in the region of residence, as compared to one year prior to the sampling.

Educational level. We consider the following categories:

Illiterate and no schooling

Primary education

Low secondary education

Upper secondary education

Higher education

Household composition. The persons living in a household are asked about their relationship with the household. Taking into account the organisation of the survey we constructed a coding system to be able to assign to each head of household variables such as wife working the previous year, children, children younger than 16 , and children working the previous year.

If the individual is not head of household, we only know whether he is single or married.

Economic sector one year prior to the sampling. For people who were employed a year before the survey, the survey provides their economic sector at the time, following the two digit classification of the CNAE, which we group into agriculture, industry, construction and services. 
Professional status one year before the interview. Individuals employed the previous year provide their professional status at the time, and we classify them into employees and self-employed, and the former into wage earners in the public sector and in the private sector.

Situation with respect to the labour market one yeer before the interview. People in our sample are classified as employed, or unemployed, all refered to the year prior to the survey.

Job tenure. We define a job tenure dummy for people whose job tenure last year was three years or over. To construct this variable we use information about current working status, current tenure, prior-year working status, tenure in last-held job, and time elapsed since last job.

Proxy for people registered at the Enmployment Office (INEM) one year before the interview. Individuals answer a question stating whether they are currently registered at the State Employment Office but no information is provided on the status the previous year. A proxy for registration one year before is constructed by assuming that people currently registered who were unemployed last year were also registered last year.

In Table A1 we provide the sample frequencies of the individual variables.

Regional Economic Variables.

We assign to each individual his corresponding regional economic variables, according to his region of residence the previous year. It is important to emphasise that the survey data for the 2nd quarter of 1991 assesses the migration behaviour with respect to the 2nd quarter of 1990 (i.e. if the individual has changed residence (moved) between the 2nd quarter of 1990 and the 2nd quarter of 1991). We assume that the individual makes the migration decision between both quarters taking into account the economic information of the year prior to the 2nd quarter of reference. 
Therefore, the economic information relevant to the migration decision between 1990 (2nd quarter) and.1991 (2nd quarter) will be the one prevailing between the 2nd quarter of 1989 and the 1st quarter of 1990 , both included. In the Tables labelled A2 the series under 1990, for example, are the average between 1989 ( $2^{\text {nd }}$ quarter) and $1990{\text { ( } 1^{\text {st }}}^{\text {s }}$ quarter) and will be used as explanatory variables of the migration decision observed in the 1991 ( $2^{\text {nd }}$ quarter) EPA.

The influence of regional economic variables is introduced as the difference between the regional value of the variable and the national one.

The variables considered are:

Unemployment rate. Source: "Encuesta de Población Activa" (EPA) and "Series Revisadas EPA (1977-87)", INE.

We also tried the regional and national unemployment rates disaggregated by economic sector. If the individuals are employed they are assigned to the unemployment rate differential of their economic sector, but.if they are unemployed we have two cases: if they worked in the past we assign to them the economic sector unemployment rate differential of the last job held, and if they do not have previous work experience we assign to them the general unemployment rate differential.

Vacancies. The vacancy rate is defined as the ratio of the region's vacancies to the region's labour force. Source: "Estadisticas de Empleo", "Instituto Nacional de Empleo" (INEM).

The vacancies differential has also been disaggregated by economic sector.

Labour Market tightness. Labour market tightness is defined as the ratio of unemployment to vacancies (Pissarides, 1991).

Cost of living. The cost-of-living variable is the Consumer Price Index (IPC). Source: INE. 
Real wage. The differential is taken to be the difference between the logarithms of regional real wages and national real wages. Source: "Contabilidad Regional de España" and "Encuesta de Salarios" (INE).

Real house price. The regional differential is defined as the difference between the logarithms of regional real house prices and the national real house price. Source: "Sociedad de Tasación".

Rate of change of participation rate. Source: "Encuesta de Población Activa" (EPA) and "Series Revisadas EPA (1977-87)", INE.

Employment growth rate. Source: "Encuesta de Población Activa (EPA)" and "Series Revisadas EPA (1977-87)", INE.

In Tables A2 we report the series used for the different general economic variables. We also present figures showing the differentials over time of the regional economic variables that turned out to affect significantly the migration decision. 
Table Al. Personal characteriatics

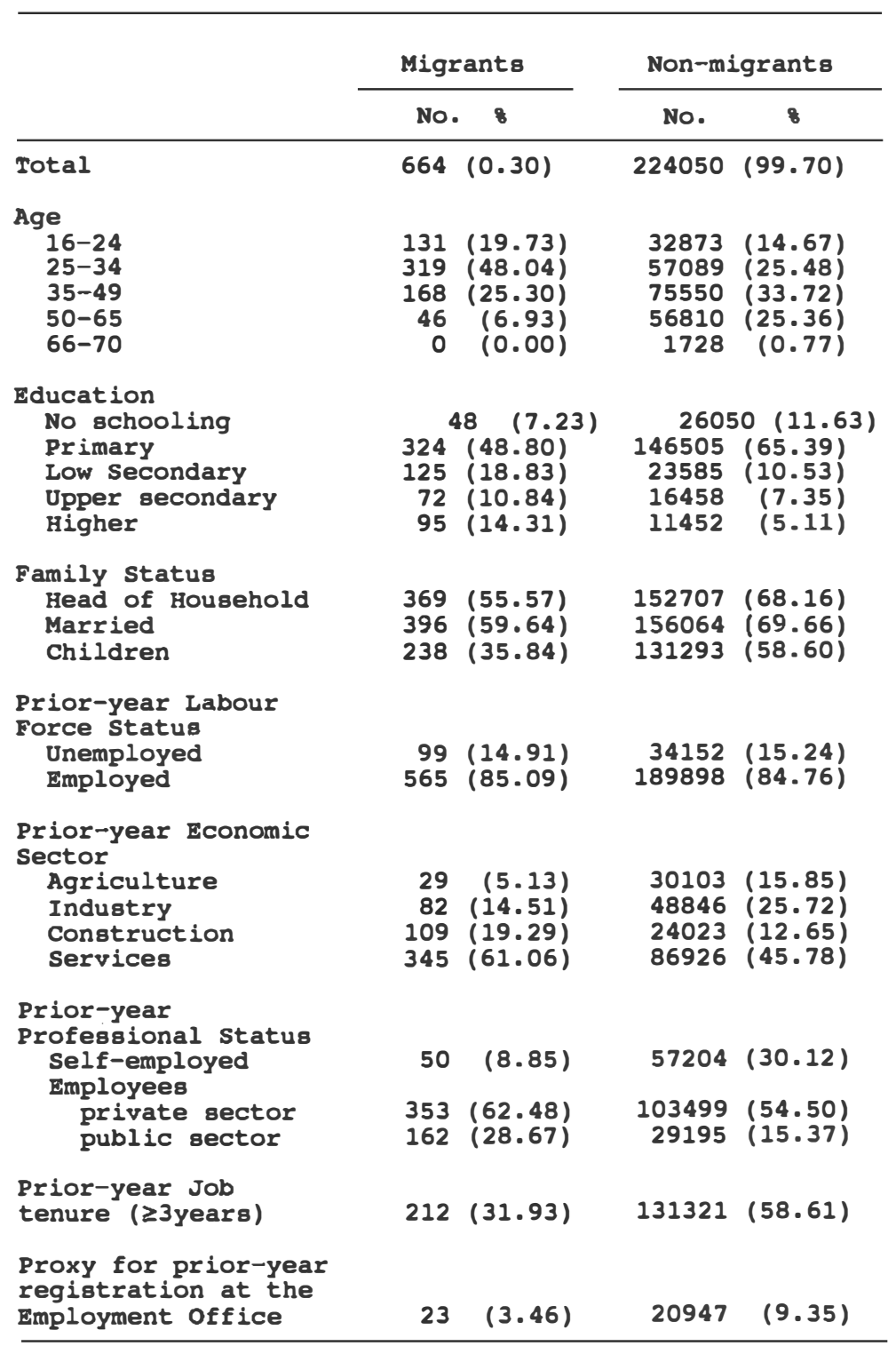


Figure 1: Regional Unemployment Differentials

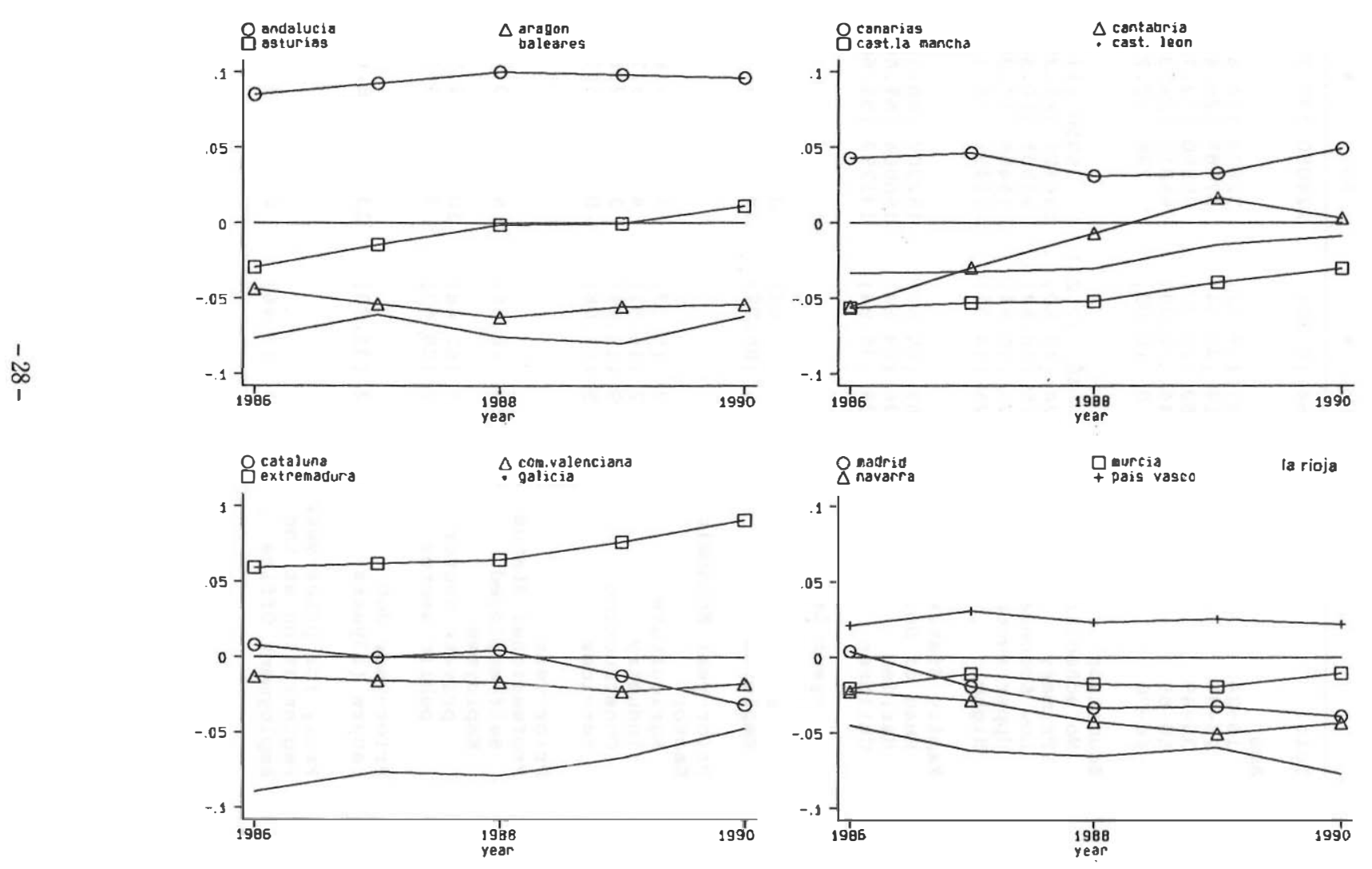


Figure 2: Regional Real Wage Differentials
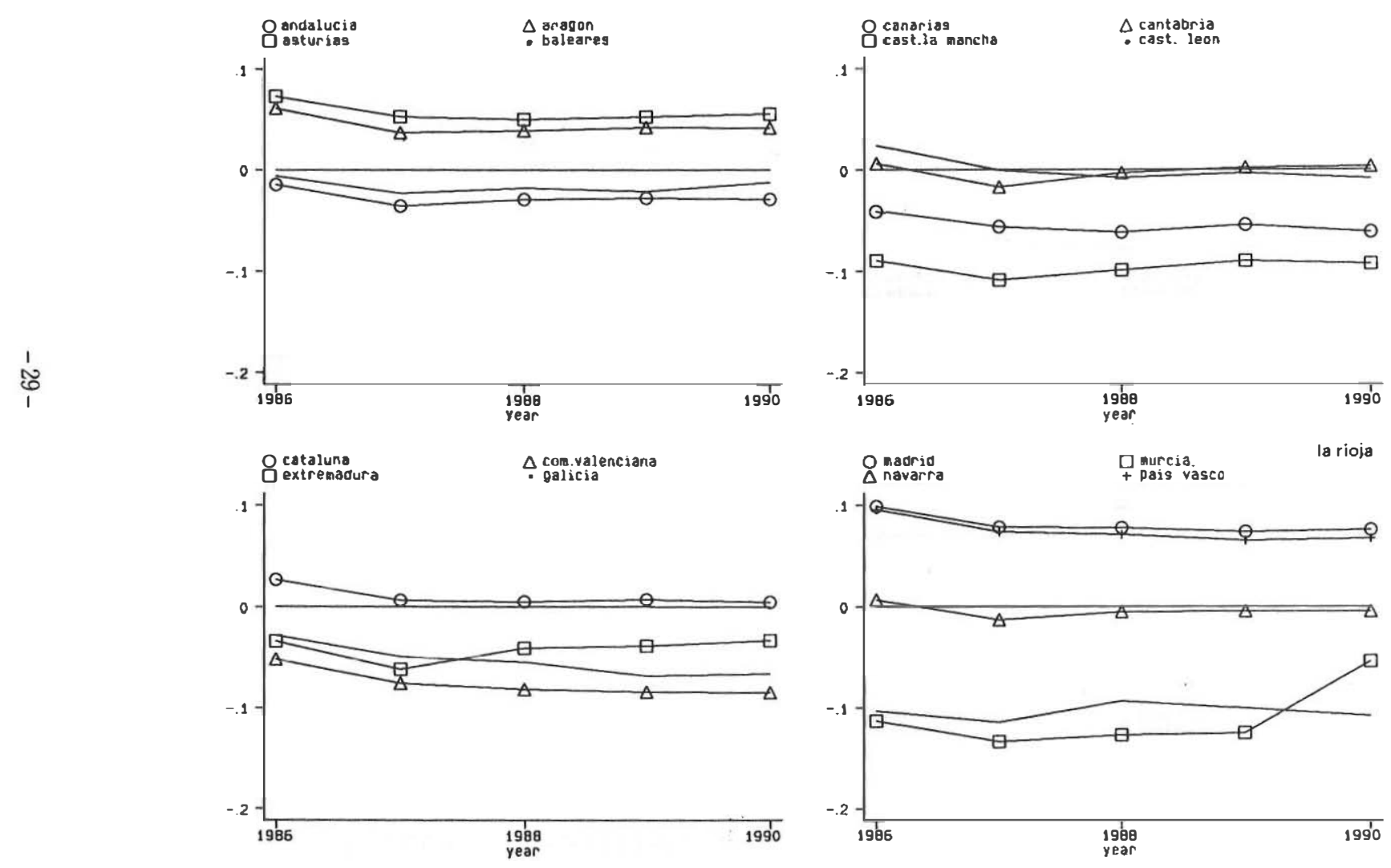
Figure 3: Regional Real House Price Differentials
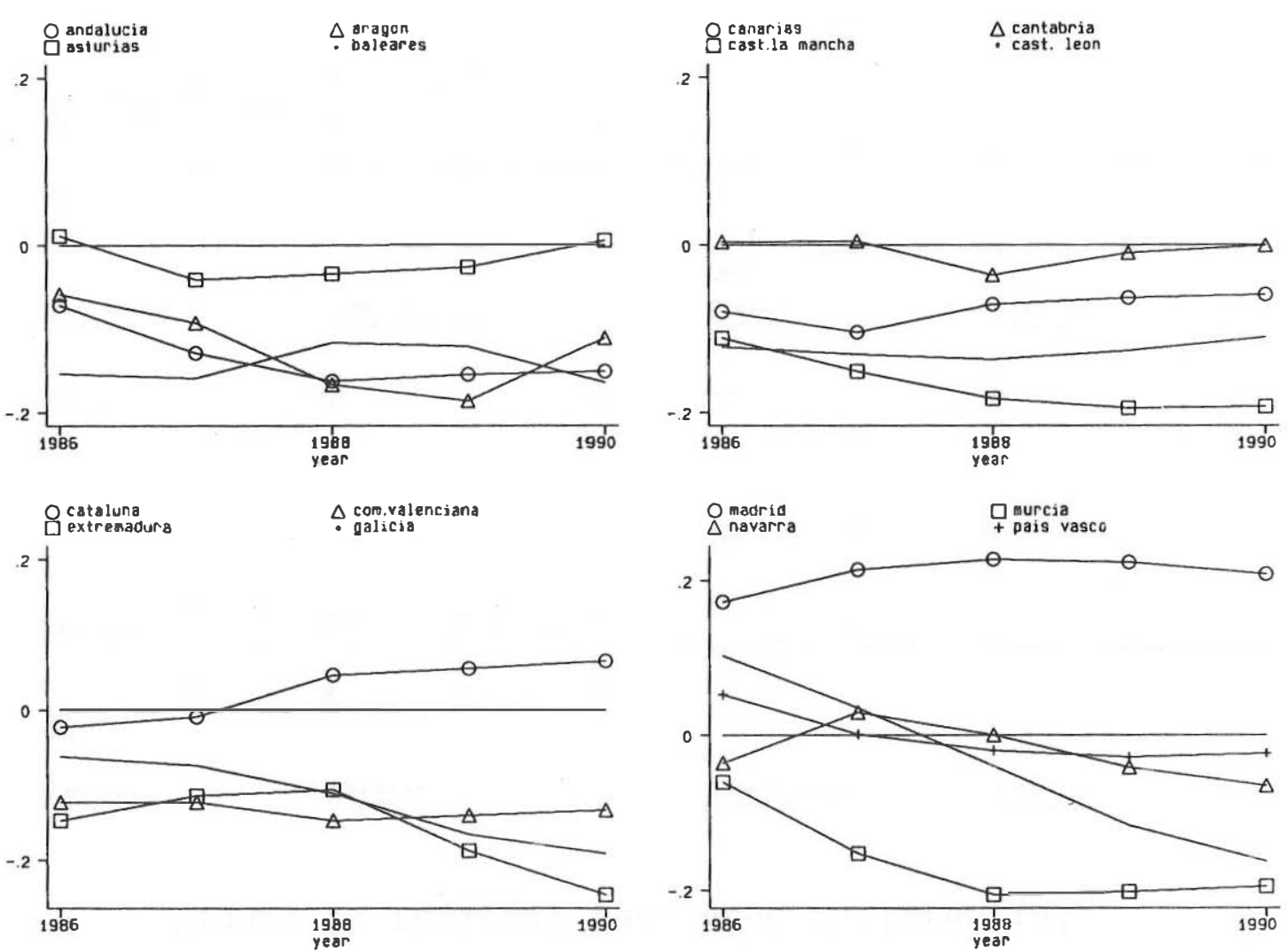


\section{Figure 4 :}

Regional Differentials in Participation Rate Growth
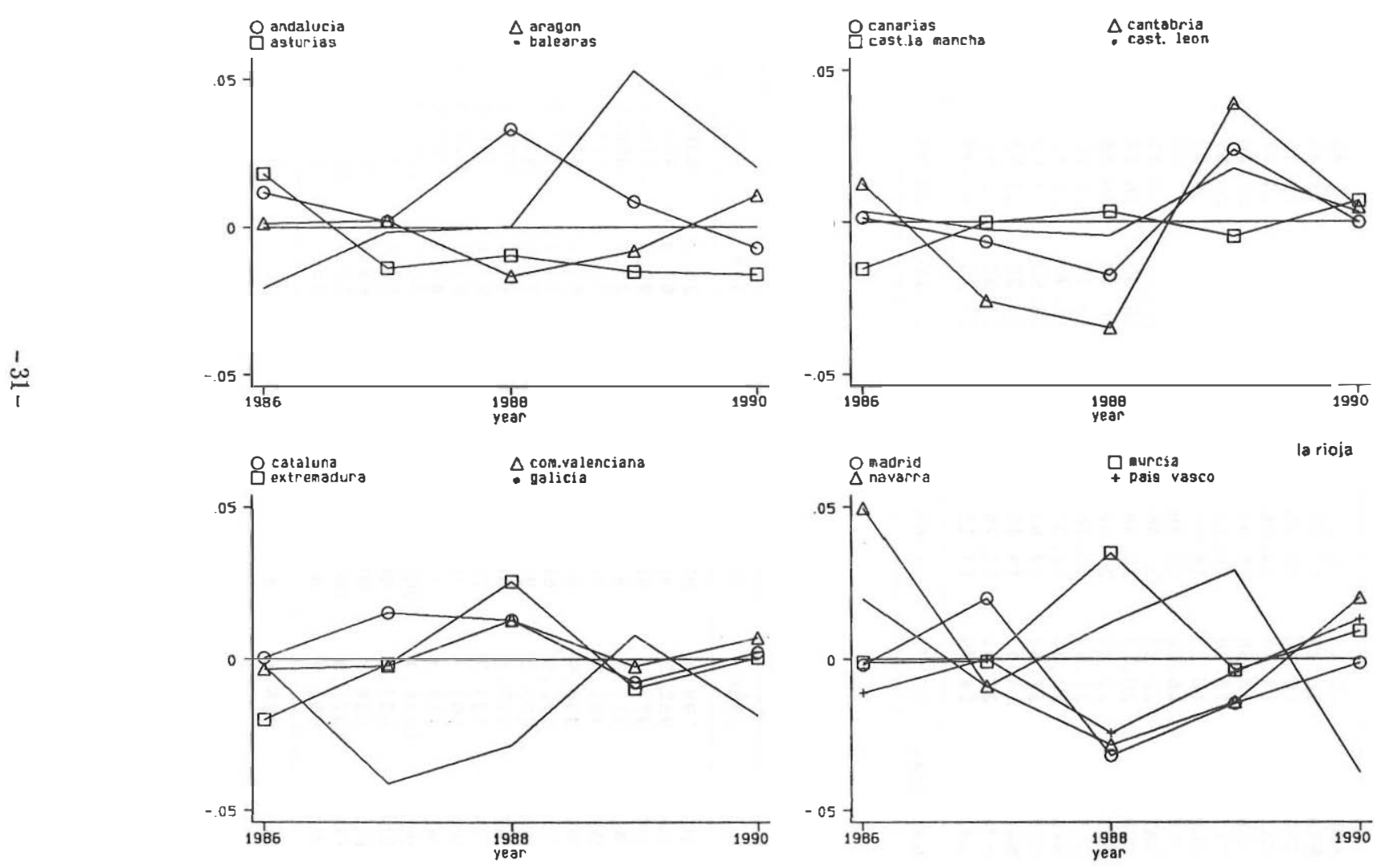
Table A2. Regional Bconomic Data

Table 2.1 Unemployment rate (s)

\begin{tabular}{lccccccr}
\hline & 1985 & 1986 & 1987 & 1988 & 1989 & 1990 & 1991 \\
\hline AND & 29.11 & 30.23 & 30.35 & 30.27 & 28.82 & 26.48 & 25.52 \\
ARA & 16.29 & 17.31 & 15.69 & 13.99 & 13.41 & 11.40 & 9.16 \\
AST & 16.40 & 18.75 & 19.66 & 20.14 & 18.92 & 17.96 & 16.66 \\
BAL & 13.79 & 14.06 & 14.98 & 12.73 & 10.96 & 10.62 & 10.61 \\
CAN & 23.56 & 25.94 & 25.71 & 23.32 & 22.20 & 21.73 & 23.21 \\
CNT & 15.39 & 16.13 & 18.10 & 19.54 & 20.59 & 17.15 & 16.23 \\
CLM & 16.73 & 16.01 & 15.78 & 15.05 & 15.03 & 13.82 & 12.79 \\
CLE & 16.52 & 18.36 & 17.86 & 17.25 & 17.52 & 15.98 & 15.25 \\
CAT & 22.28 & 22.46 & 21.05 & 20.75 & 17.72 & 13.69 & 12.48 \\
CVA & 20.19 & 20.38 & 19.52 & 18.60 & 16.68 & 15.05 & 14.40 \\
EXT & 27.41 & 27.62 & 27.28 & 26.70 & 26.58 & 25.90 & 23.80 \\
GAL & 11.97 & 12.76 & 13.48 & 12.38 & 12.30 & 12.11 & 11.94 \\
MAD & 20.80 & 22.07 & 19.15 & 16.90 & 15.72 & 12.91 & 12.17 \\
MUR & 18.43 & 19.63 & 19.99 & 18.50 & 17.03 & 15.78 & 16.24 \\
NAV & 16.49 & 19.40 & 18.24 & 16.00 & 13.93 & 12.47 & 11.31 \\
PVA & 22.61 & 23.79 & 24.14 & 22.59 & 21.52 & 19.03 & 18.63 \\
LRJ & 14.79 & 17.15 & 14.90 & 13.70 & 12.99 & 9.12 & 8.94 \\
\hline National & 20.75 & 21.69 & 21.09 & 20.26 & 18.96 & 16.84 & 16.08 \\
\hline
\end{tabular}

Table A2.2. Real wagea

\begin{tabular}{lrrrrrr}
\hline & \multicolumn{1}{c}{1986} & \multicolumn{1}{c}{1987} & 1988 & 1989 & 1990 & \multicolumn{1}{c}{1991} \\
\hline AND & 799.8 & 805.2 & 831.1 & 824.1 & 836.2 & 837.4 \\
ARA & 952.2 & 951.3 & 971.3 & 967.9 & 983.1 & 975.4 \\
AST & 977.7 & 986.1 & 996.4 & 991.0 & 1015.6 & 1016.2 \\
BAL & 815.3 & 828.9 & 852.6 & 835.9 & 868.5 & 850.6 \\
CAN & 752.7 & 767.6 & 772.3 & 775.7 & 777.7 & 783.8 \\
CNT & 838.4 & 840.0 & 882.4 & 881.6 & 901.1 & 919.1 \\
CLM & 672.6 & 680.7 & 708.4 & 714.2 & 723.0 & 738.6 \\
CWE & 873.0 & 872.1 & 871.9 & 871.8 & 876.7 & 894.3 \\
CAT & 879.2 & 886.6 & 899.6 & 893.2 & 903.2 & 905.7 \\
CVA & 733.0 & 733.4 & 736.6 & 723.6 & 735.4 & 761.7 \\
EXT & 763.9 & 757.2 & 808.2 & 802.3 & 827.3 & 808.8 \\
GAL & 774.3 & 779.4 & 783.2 & 749.7 & 767.5 & 780.1 \\
MAD & 1036.9 & 1046.8 & 1061.7 & 1040.7 & 1064.2 & 1087.8 \\
MUR & 637.2 & 642.2 & 663.6 & 658.6 & 788.1 & 743.4 \\
NAV & 838.8 & 847.7 & 877.8 & 868.6 & 884.8 & 894.7 \\
PVA & 1028.8 & 1034.4 & 1046.8 & 1019.7 & 1042.3 & 1071.5 \\
LRJ & 651.9 & 671.2 & 716.5 & 696.7 & 696.9 & 712.5 \\
\hline Nat. & 826.6 & 873.6 & 888.5 & 878.1 & 893.9 & 906.9 \\
\hline
\end{tabular}


Table 22.3. Real Houge prices

\begin{tabular}{|c|c|c|c|c|c|c|}
\hline & 1986 & 1987 & 1988 & 1989 & 1990 & 1991 \\
\hline $\begin{array}{l}\text { AND } \\
\text { ARA } \\
\text { AST } \\
\text { BAL } \\
\text { CAN } \\
\text { CNT } \\
\text { CRY } \\
\text { CLE } \\
\text { CAT } \\
\text { CVA } \\
\text { EXT } \\
\text { GAL } \\
\text { MAD } \\
\text { MUR } \\
\text { NAV } \\
\text { PVA } \\
\text { LRJ }\end{array}$ & $\begin{array}{l}399.859 \\
412.279 \\
484.601 \\
330.879 \\
392.309 \\
475.725 \\
365.006 \\
356.393 \\
447.637 \\
355.664 \\
336.288 \\
409.238 \\
700.534 \\
410.492 \\
434.282 \\
531.827 \\
598.285\end{array}$ & $\begin{array}{l}415.061 \\
450.151 \\
507.195 \\
387.506 \\
439.090 \\
563.621 \\
394.462 \\
412.806 \\
546.503 \\
420.412 \\
429.733 \\
470.951 \\
913.944 \\
392.476 \\
597.865 \\
559.280 \\
605.916\end{array}$ & $\begin{array}{r}472.393 \\
467.778 \\
634.753 \\
524.735 \\
583.358 \\
632.341 \\
450.733 \\
501.530 \\
764.136 \\
489.571 \\
538.154 \\
531.788 \\
1159.466 \\
427.743 \\
686.852 \\
656.915 \\
626.329\end{array}$ & $\begin{array}{r}581.211 \\
541.120 \\
780.210 \\
628.221 \\
717.175 \\
811.384 \\
529.593 \\
620.642 \\
943.175 \\
600.298 \\
539.631 \\
567.025 \\
1387.445 \\
521.226 \\
753.515 \\
776.735 \\
634.882\end{array}$ & $\begin{array}{r}661.760 \\
725.302 \\
949.663 \\
642.180 \\
817.132 \\
935.382 \\
601.434 \\
726.439 \\
1088.616 \\
689.040 \\
532.477 \\
603.337 \\
1515.976 \\
598.515 \\
807.155 \\
889.100 \\
644.307\end{array}$ & $\begin{array}{r}671.151 \\
723.934 \\
906.843 \\
681.943 \\
814.296 \\
951.510 \\
616.268 \\
745.757 \\
1142.943 \\
665.979 \\
522.447 \\
645.921 \\
1447.337 \\
623.705 \\
825.263 \\
927.538 \\
671.996\end{array}$ \\
\hline Nat. & 471.658 & 558.072 & 686.915 & 829.817 & 937.608 & 938.348 \\
\hline
\end{tabular}

Table 22.4. Rate of change of participation rate

\begin{tabular}{lrrrrrr}
\hline & 1986 & 1987 & 1988 & 1989 & 1990 & \multicolumn{1}{c}{1991} \\
\hline AND & 0.007720 & 0.010122 & 0.058193 & 0.007615 & -0.003703 & -0.003298 \\
ARA & -0.002695 & 0.010291 & 0.008452 & -0.009170 & 0.014117 & 0.008138 \\
AST & 0.014002 & -0.005788 & 0.015463 & -0.016151 & -0.012588 & -0.014724 \\
BAL & -0.024628 & 0.006493 & 0.025196 & 0.052047 & 0.023439 & -0.000880 \\
CAN & -0.002617 & 0.001702 & 0.007424 & 0.022429 & 0.003366 & -0.013040 \\
CNT & 0.008609 & -0.017786 & -0.009954 & 0.037723 & 0.008227 & -0.021726 \\
CLM & -0.019146 & 0.007955 & 0.028225 & -0.005719 & 0.010269 & -0.010432 \\
CLE & -0.000479 & 0.005447 & 0.020386 & 0.016424 & 0.006598 & 0.010787 \\
CAT & -0.003537 & 0.023403 & 0.038034 & -0.008697 & 0.005753 & 0.010526 \\
CVA & -0.007176 & 0.005948 & 0.037999 & -0.003305 & 0.010435 & 0.015390 \\
EXT & -0.023820 & 0.006665 & 0.050595 & -0.010604 & 0.003951 & 0.010074 \\
GAL & -0.006074 & -0.032828 & -0.003229 & 0.007022 & -0.015060 & -0.026802 \\
MAD & -0.005939 & 0.028122 & -0.006779 & -0.015678 & 0.002146 & 0.018260 \\
MUR & -0.005114 & 0.007322 & 0.059814 & -0.004676 & 0.012811 & 0.030003 \\
NAV & 0.045722 & -0.000856 & -0.003251 & -0.015316 & 0.023760 & 0.008241 \\
PVA & -0.015192 & 0.008188 & 0.000670 & -0.005280 & 0.016753 & 0.028439 \\
LRJ & 0.015731 & -0.001036 & 0.037124 & 0.028097 & -0.033874 & -0.086018 \\
\hline Nat. & -0.003893 & 0.008187 & 0.025028 & -0.000945 & 0.003529 & 0.004270 \\
\hline
\end{tabular}


Table A2.5. Vacancy rates (8)

\begin{tabular}{lcccccc}
\hline & 1986 & 1987 & 1988 & 1989 & 1990 & 1991 \\
\hline AND & 0.3256 & 0.3126 & 0.3722 & 0.3598 & 0.4295 & 0.4549 \\
ARA & 0.2494 & 0.2634 & 0.2856 & 0.2912 & 0.2847 & 0.2374 \\
AST & 0.5175 & 0.6095 & 0.4094 & 0.4629 & 0.5950 & 0.6823 \\
BAL & 0.2336 & 0.4276 & 0.4872 & 0.6484 & 0.5034 & 0.3499 \\
CAN & 0.3023 & 0.3801 & 0.4376 & 0.6920 & 0.4487 & 0.3308 \\
CNT & 0.2937 & 0.2492 & 0.3136 & 0.3509 & 0.4164 & 0.2791 \\
CLM & 0.4254 & 0.4044 & 0.4902 & 0.4710 & 0.5983 & 0.5738 \\
CLE & 0.2486 & 0.3112 & 0.3369 & 0.3569 & 0.2690 & 0.2497 \\
CAT & 0.3473 & 0.3632 & 0.3228 & 0.3943 & 0.3640 & 0.2498 \\
CVA & 0.3667 & 0.2941 & 0.3553 & 0.3834 & 0.3605 & 0.2679 \\
EXT & 0.3424 & 0.3492 & 0.3059 & 0.3302 & 0.2475 & 0.3252 \\
GAL & 0.2690 & 0.1940 & 0.2201 & 0.2957 & 0.3563 & 0.3557 \\
MAD & 0.2134 & 0.2251 & 0.2351 & 0.3356 & 0.3239 & 0.2655 \\
MUR & 0.4512 & 0.4513 & 0.4514 & 0.6262 & 0.8517 & 0.6296 \\
NAV & 0.4560 & 0.4705 & 0.5309 & 0.4607 & 0.4624 & 0.3240 \\
PVA & 0.3407 & 0.2654 & 0.3013 & 0.2522 & 0.2408 & 0.1613 \\
LRJ & 0.2930 & 0.5262 & 0.3030 & 0.3160 & 0.5556 & 0.4613 \\
\hline Nat. & 0.3197 & 0.3180 & 0.3353 & 0.3839 & 0.3879 & 0.3348 \\
\hline
\end{tabular}

Table A2.6. Rate of change of employment

\begin{tabular}{lrrrcrr}
\hline & 1986 & 1987 & 1988 & 1989 & 1990 & \multicolumn{1}{c}{1991} \\
\hline AND & 0.010387 & 0.027345 & 0.079720 & 0.047445 & 0.046836 & 0.020955 \\
ARA & -0.008485 & 0.044319 & 0.034644 & 0.006439 & 0.046641 & 0.019072 \\
AST & -0.009038 & -0.013644 & 0.017161 & 0.005818 & 0.006290 & 0.027087 \\
BAI & -0.018154 & 0.001921 & 0.070821 & 0.086392 & 0.038422 & -0.023113 \\
CAN & -0.012333 & 0.024708 & 0.073444 & 0.061680 & 0.030192 & -0.030029 \\
CNT & 0.006665 & -0.029004 & -0.017370 & 0.035189 & 0.063677 & -0.010353 \\
CLM & 0.022463 & 0.014024 & 0.040860 & 0.027030 & 0.032763 & 0.003048 \\
CLE & -0.028808 & 0.023034 & 0.044016 & 0.000313 & 0.039139 & 0.015349 \\
CAT & 0.002482 & 0.051598 & 0.054458 & 0.039523 & 0.065302 & 0.033967 \\
CVA & 0.002560 & 0.022908 & 0.069932 & 0.031867 & 0.042643 & 0.026139 \\
EXT & -0.009449 & 0.021316 & 0.075193 & 0.003280 & 0.025797 & 0.041168 \\
GAI & -0.005843 & -0.034522 & 0.021245 & 0.016010 & -0.005053 & -0.009724 \\
MAD & -0.004939 & 0.083015 & 0.032848 & 0.013044 & 0.050725 & 0.030305 \\
MUR & 0.002926 & 0.012235 & 0.105346 & 0.030535 & 0.044568 & 0.016566 \\
NAV & 0.023988 & 0.025498 & 0.032323 & 0.021526 & 0.052608 & 0.003500 \\
PVA & -0.019379 & 0.015047 & 0.031829 & 0.019612 & 0.060240 & 0.019699 \\
LRJ & -0.000660 & 0.044899 & 0.056872 & 0.049327 & 0.019658 & -0.057558 \\
\hline Nat. & -0.002455 & 0.027560 & 0.050564 & 0.028205 & 0.042631 & 0.017608 \\
\hline
\end{tabular}


Table A2.7. Price index

\begin{tabular}{lcccccc}
\hline & 1986 & 1987 & 1988 & 1989 & 1990 & 1991 \\
\hline AND & 122.731 & 133.655 & 139.767 & 146.290 & 156.099 & 166.617 \\
ARA & 121.823 & 131.345 & 137.565 & 145.070 & 154.591 & 164.621 \\
AST & 121.853 & 131.015 & 136.628 & 143.455 & 153.291 & 163.479 \\
BAI & 122.175 & 132.708 & 138.880 & 145.490 & 154.552 & 163.504 \\
CAN & 120.186 & 127.651 & 134.223 & 139.053 & 148.905 & 157.959 \\
CNT & 122.655 & 132.359 & 137.703 & 144.075 & 152.344 & 161.060 \\
CLM & 121.642 & 130.494 & 136.278 & 142.138 & 151.388 & 160.482 \\
CLE & 122.828 & 131.963 & 137.679 & 144.488 & 153.936 & 163.458 \\
CAT & 122.365 & 132.936 & 140.158 & 147.136 & 158.160 & 169.956 \\
CVA & 124.345 & 133.738 & 140.480 & 148.676 & 159.171 & 169.037 \\
EXT & 123.034 & 132.524 & 137.879 & 144.219 & 153.246 & 161.261 \\
GAL & 121.995 & 132.551 & 139.294 & 147.216 & 158.038 & 167.861 \\
MAD & 122.157 & 131.162 & 136.593 & 145.754 & 156.170 & 165.822 \\
MUR & 121.805 & 131.409 & 138.401 & 144.755 & 156.638 & 167.146 \\
NAV & 121.753 & 131.761 & 138.822 & 145.551 & 154.803 & 165.705 \\
PVA & 124.148 & 134.816 & 142.256 & 150.309 & 160.106 & 170.128 \\
LRJ & 126.696 & 135.250 & 141.579 & 151.091 & 163.005 & 174.108 \\
\hline Nat. & 122.599 & 132.196 & 138.481 & 145.574 & 155.555 & 165.424 \\
\hline
\end{tabular}

Table A2.8. Participation rate

\begin{tabular}{lccccccc}
\hline & 1985 & 1986 & 1987 & 1988 & 1989 & 1990 & 1991 \\
\hline AND & 0.434885 & 0.438242 & 0.442678 & 0.468439 & 0.472006 & 0.470258 & 0.470449 \\
ARA & 0.458884 & 0.457648 & 0.462357 & 0.466266 & 0.461990 & 0.468512 & 0.465749 \\
AST & 0.472092 & 0.478703 & 0.475932 & 0.483291 & 0.475486 & 0.469500 & 0.468485 \\
BAL & 0.493480 & 0.481327 & 0.484452 & 0.496658 & 0.522508 & 0.534755 & 0.522048 \\
CAN & 0.501200 & 0.499889 & 0.500739 & 0.504457 & 0.515771 & 0.517508 & 0.509046 \\
CNT & 0.476276 & 0.480376 & 0.471832 & 0.467135 & 0.484757 & 0.488745 & 0.474225 \\
CLE & 0.458320 & 0.449545 & 0.453121 & 0.465911 & 0.463246 & 0.468003 & 0.468243 \\
CLM & 0.435342 & 0.435133 & 0.437504 & 0.446423 & 0.453754 & 0.456748 & 0.449021 \\
CAT & 0.496727 & 0.494971 & 0.506554 & 0.525821 & 0.521248 & 0.524247 & 0.526734 \\
CVA & 0.488492 & 0.484986 & 0.487871 & 0.506409 & 0.504736 & 0.510003 & 0.512503 \\
EXT & 0.437357 & 0.426939 & 0.429784 & 0.451529 & 0.446741 & 0.448506 & 0.451241 \\
GAL & 0.551083 & 0.547736 & 0.529755 & 0.528044 & 0.531752 & 0.523743 & 0.517500 \\
MAD & 0.479635 & 0.476786 & 0.490195 & 0.486872 & 0.479238 & 0.480267 & 0.487989 \\
MUR & 0.464435 & 0.462060 & 0.465443 & 0.493283 & 0.490977 & 0.497267 & 0.505707 \\
NAV & 0.471745 & 0.493315 & 0.492892 & 0.491290 & 0.483765 & 0.495260 & 0.487752 \\
PVA & 0.498836 & 0.491258 & 0.495280 & 0.495612 & 0.492995 & 0.501254 & 0.507015 \\
LRJ & 0.450824 & 0.457916 & 0.457442 & 0.474424 & 0.487754 & 0.471232 & 0.445798 \\
\hline Nat. & 0.476931 & 0.475075 & 0.478964 & 0.490951 & 0.490487 & 0.492218 & 0.492582 \\
\hline
\end{tabular}


1. It should also be noted that sometimes it has been found that the effects of destination characteristics are not as precisely perceived (estimated) as the origin ones (see Gabriel et al. (1991)).

2. We do not model the joint decisions involved at the household level but we take into account the family structure as one factor influencing individuals' decision.

3. We also exclude those individuals who

(i) did not answer the questions about their relationship with the labour market the previous year (these are generally people younger than 16 the previous year)

(ii) did not answer the question about their situation with respect to the Employment Office

(iii) report being in the army either at the time of the survey or the previous year.

4. To reach our final specification, aside from the single coefficient t-tests we used Wald tests for the joint significance of some parameters and those proved relevant due to the existence in some cases of high collinearity, depending on how the dummy variables were defined. For our chosen measure of goodness of fit we looked at the association of predicted probabilities and observed responses. This measures how many pairs of observations have a concordant response, i.e. how many pairs (with our sample we have over 165 million pairs) with different observed responses have predicted probabilities that rank accordingly. This measure makes more sense in our case than a frequency table of observed and predicted responses. This table would be heavily dependent on the cut off probability point chosen, above which migration is predicted. This is specially important in our case where predicted probabilities in our sample range from 0.000025 to 0.1929 with a mean of 0.00295 .

5. A detailed description of the variables can be found in the Data Appendix.

6. The results do not change if we allow for more disaggregated children dummies.

7. We also considered a sample that includes men out of the labour force, either at the time of sampling or in the previous year. Among people out of the labour force the previous year, only students seem to have a higher probability of migrating than the standard employed person, and the rest basically do not respond to economic incentives. The parameter estimates are robust to this change of sample, except for people in the age group 16 to 24 who now have the same probability of migrating (other things being equal) as those aged 35 to 49 ; this is to be expected given the inclusion of young dependants in the extended sample. 
8. In going from Table 4 col. 4 to Table 2 col. 1 we drop the insignificant regional unemployment differential. In order to calculate the predicted probabilities for different cases (Table 3) it would be misleading to retain it.

9. Cost-of-living regional differentials measured from the Consumer Price Index were not significant in our model.

10. Not allowing for different coefficients for higher-than-average house price regions and for lower-than-average ones produces a parameter estimate of $0.92(t-r a t i o=4.6)$, and no significant change to the other estimates. This is a reasonable estimate. However, the investment decision involved in owner occupation leads us to allow for an asymmetric treatment of the effect of house prices. Aside from this asymmetric ef fect being empirically significant, the statistics measuring the association of predicted probabilities and observed responses improved. Note that asymmetries in unemployment, participation change and wage differentials are not supported by the data.

11. We have also estimated our model dropping the individuals (53 of them) who, despite having changed their region of residence, declare themselves to be still working in their previous region. It is the case that most of these moves are to non-contiguous regions, however one could think that these individuals have a seasonal job (this hypothesis is confirmed by their occupation) and may go back when needed for work. Therefore, as far as the labour market is concerned, they have not migrated. Despite leaving them out our results do not change.

12. Once we divide the logit estimates by $(\pi / \sqrt{3})$, to allow for the fact that the standard deviation of the logistic distribution is $(\pi / \sqrt{3})$ while that of the standard normal distribution is unity. The remaining difference will be due to the difference in the distribution function.

13. We are starting research on these lines.

14. The number of degrees of freedom is given by the number of parameters in the model estimated with the first subsample plus the number of parameters in the model estimated with the second subsample minus the number of parameters in the model estimated with the complete sample.

15. We have, of course, already dropped the variables that a priori cannot be identified given the nature of the subsample. 
TRABB 1

Outmigration and imnigration between the Spanish regions, (1987-1991). Sample of adult mon in the labour force

\begin{tabular}{||l|c|c||}
\hline & Outmigrants & \begin{tabular}{c} 
Immigrants \\
\hline
\end{tabular} \\
\hline Andalucía & 11.6 & 18.07 \\
Aragón & 3.61 & 4.07 \\
Asturias & 2.56 & 2.41 \\
Baleares & 6.93 & 3.31 \\
Canarias & 3.77 & 4.52 \\
Cantabria & 0.45 & 2.86 \\
Castilla la Mancha & 4.07 & 10.54 \\
Castilla-León & 9.04 & 12.50 \\
Cataluña & 11.9 & 5.12 \\
Comunidad Valenciana & 6.02 & 5.12 \\
Extremadura & 2.86 & 8.89 \\
Galicia & 4.37 & 6.33 \\
Madrid & 20.03 & 2.71 \\
Murcia & 2.41 & 3.16 \\
Navarra & 1.96 & 3.16 \\
País Vasco & 7.53 & 4.52 \\
La Rioja & 0.90 & 2.71 \\
& 100 & 100 \\
\hline \hline
\end{tabular}

Source: "Encuesta de Migraciones", INE. 
TERTB 2

Final Betimated kigration Bquationg Gging Pooled Cross-sections

\begin{tabular}{|c|c|c|c|c|}
\hline & $(\log i t)$ & (probit) & \multicolumn{2}{|c|}{$\left(\log ^{3} 1 t\right)$} \\
\hline conatant ${ }^{2}$ & $-5.012(22.22)$ & $-2.423(31.88)$ & -4.833 & $(20.59)$ \\
\hline aged 16 to 24 & $0.422 \quad(2.83)$ & $0.144 \quad(2.73)$ & 0.404 & $(2.72)$ \\
\hline aged 25 to 34 & $0.516 \quad(4.87)$ & $(4.97)$ & 0.512 & $(4.83)$ \\
\hline aged 50 to 70 & $-1.031 \quad(6.11)$ & -0.328 & -1.035 & $(6.13)$ \\
\hline primary education & $-0.441 \quad(5.03)$ & -0.157 & -0.451 & $(5.15)$ \\
\hline higher education & $0.423 \quad(3.29)$ & $(3.48)$ & 0.416 & $(3.24)$ \\
\hline children & $-1.019(10.00)$ & -0.360 & -1.027 & $(10.07)$ \\
\hline $\begin{array}{l}\text { not head of hous ehold, } \\
\text { gingle (nhhs) }\end{array}$ & $-1.341(11.87)$ & $-0.471(11.31)$ & -1.331 & $(11.78)$ \\
\hline married with working wife & $-0.641 \quad(4.85)$ & -0.223 & -0.630 & $(4.77)$ \\
\hline unemployed & $0.605 \quad(2.85)$ & $(2.40)$ & 0.588 & $(2.76)$ \\
\hline registered at INEM & $-1.484 \quad(5.96)$ & -0.497 & -1.511 & $(6.07)$ \\
\hline tenure $\geq 3$ yeara & $-0.966 \quad(9.78)$ & -0.340 & -0.980 & $(9.93)$ \\
\hline $\begin{array}{l}\text { employee in public } \\
\text { eector }\end{array}$ & $(8.03)$ & $(8.22)$ & 1.366 & $(8.01)$ \\
\hline $\begin{array}{l}\text { employee in private } \\
\text { eector }\end{array}$ & $(5.99)$ & $(5.97)$ & 0.945 & $(6.05)$ \\
\hline agriculture & -0.687 & -0.217 & -0.718 & $(3.33)$ \\
\hline industry & -0.890 & -0.312 & -0.891 & $(5.94)$ \\
\hline services & -0.234 & -0.089 & -0.238 & $(1.96)$ \\
\hline Unemployment difEerential & -- & - & & -- \\
\hline Unempl.diff.*unemployed & $(1.60)$ & $(1.65)$ & 3.743 & $(1.65)$ \\
\hline$" \quad$ *registered & -13.808 & -4.621 & -13.643 & $(2.85)$ \\
\hline " $\quad$ *higher educ. & $(1.73)$ & $(1.55)$ & 4.114 & $(1.70)$ \\
\hline "children & -5.129 & -1.757 & -5.103 & $(3.74)$ \\
\hline$" \quad$ *nhhs & -8.316 & -2.852 & -8.267 & $(4.80)$ \\
\hline $\begin{array}{l}\text { Participation rate growth } \\
\text { differential }\end{array}$ & $(4.79)$ & $(4.58)$ & 0.126 & $(4.60)$ \\
\hline $\begin{array}{l}\text { Partic. race growth diff. } \\
\text { whigher education }\end{array}$ & -0.100 & -0.027 & -0.107 & $(1.44)$ \\
\hline Bouge price differential & $(3.43)$ & $(3.77)$ & 0.663 & $(3.33)$ \\
\hline |House price differential| & $(5.62)$ & $(5.64)$ & 1.699 & $(6.12)$ \\
\hline Real Wage differential & $(5.69)$ & $(5.61)$ & 2.427 & $(5.35)$ \\
\hline D88 & -- & - & -0.136 & $(1.09)$ \\
\hline D89 & -- & -- & -0.359 & $(2.73)$ \\
\hline D9O & -- & -- & -0.261 & $(2.08)$ \\
\hline D91 & -- & -- & -0.343 & $(2.72)$ \\
\hline $\begin{array}{l}\text { Aerociat ion of predlcted } \\
\text { prob. and observed response日 }\end{array}$ & & & & \\
\hline concordant & 73.68 & 74.08 & & 73.88 \\
\hline tied & 14.28 & 13.68 & & 14.18 \\
\hline - log likelihood & 3976.04 & 3980.26 & & 3970.71 \\
\hline
\end{tabular}

NOTES:

1. $t$-ratios in brackets.

the constant term will determine the probability of migrating for individuala with the following characteristics: head of household gingle or married to non working wife (or not head, but married), aged between 35 and 49, with either no schooling or gecondary education, no children, gelf-employed in the construction gector with less than three years in the current job, and living in a hypothetlcal region where the value of the relevant regional variables equals the national average.

3. Sample bize $=224,714$. Migration frequency $=0.2958$. 
TNATRB 3

Predicted prababilities (

\begin{tabular}{|c|c|c|c|c|c|c|}
\hline \multirow[b]{3}{*}{ Standard $^{1}$} & \multicolumn{4}{|c|}{ Employed } & \multicolumn{2}{|c|}{ Unemployed } \\
\hline & Agriculture & Construction & Induatry & Services & Registered & $\begin{array}{c}\text { Not } \\
\text { registered }\end{array}$ \\
\hline & 0.35 & 0.69 & 0.28 & 0.55 & 0.30 & 1.30 \\
\hline $\begin{array}{l}\text { BUT } \\
\text { age } 35-49\end{array}$ & 0.21 & 0.41 & 0.17 & 0.33 & 0.18 & 0.78 \\
\hline Working wife & 0.18 & 0.37 & 0.15 & 0.29 & 0.16 & 0.69 \\
\hline Children & 0.13 & 0.25 & 0.10 & 0.20 & 0.11 & 0.47 \\
\hline Not head, single & 0.09 & 0.18 & 0.07 & 0.14 & 0.08 & 0.34 \\
\hline Higher education & 0.82 & 1.63 & 0.67 & 1.29 & 0.70 & 3.02 \\
\hline tenure $<3$ years & 0.91 & 1.80 & 0.75 & 1.43 & -- & - \\
\hline self-amployed & 0.14 & 0.27 & 0.11 & 0.22 & -- & -- \\
\hline \multicolumn{7}{|l|}{ REGIONAL DIFFERENTIALS } \\
\hline $\begin{array}{l}\text { House Prices= } \\
\text { (i)+0.5235 } \\
\text { (eg.Madrid 1989) }\end{array}$ & 1.07 & 2.11 & 0.88 & 1.68 & 0.91 & 3.90 \\
\hline $\begin{array}{l}\text { (11) }-0.3842 \\
\text { (eg.Arag6n 1989) }\end{array}$ & 0.47 & 0.94 & 0.39 & 0.75 & 0.40 & 1.76 \\
\hline $\begin{array}{l}\text { Participation rate of } \\
\text { change } 100=1.3 \\
\text { (eg.Cataluna 1989) }\end{array}$ & 0.41 & 0.82 & 0.34 & 0.65 & 0.35 & 1.53 \\
\hline $\begin{array}{l}\text { Unemployment rate }=0.1 \\
\text { (eg.Andalucía } 1989)\end{array}$ & 0.35 & 0.69 & 0.28 & 0.55 & 0.11 & 1.85 \\
\hline
\end{tabular}

Notes:

1. Standard: head of hougehold, age 25-34, wife not working, no children, primary education, employee private sector, tenure over three years, average region. 
FARTRE 4

Some internediate logit aodoly for the prabability of migration

\begin{tabular}{|c|c|c|c|c|c|c|c|c|}
\hline \multirow[b]{2}{*}{ constant } & \multicolumn{2}{|c|}{1} & \multicolumn{2}{|l|}{2} & \multicolumn{2}{|l|}{3} & \multicolumn{2}{|r|}{4} \\
\hline & -4.65512 & $21.78)$ & $-4.646(2$ & $21.78)$ & -4.64612 & $21.77)$ & $-4.634(2$ & $(21.67)$ \\
\hline aged 16 to 24 & 0.463 & $(3.13)$ & 0.427 & $(2.87)$ & 0.427 & $(2.87)$ & 0.423 & $(2.85)$ \\
\hline aged 25 to 34 & 0.539 ( & $(5.10)$ & 0.525 & $(4.96)$ & 0.525 ( & $(4.96)$ & 0.518 & $(4.89)$ \\
\hline aged 50 to 70 & -1.042 & $(6.19)$ & -1.015 & $(6.04)$ & -1.015 ( & $(6.04)$ & -1.011( & $(6.00)$ \\
\hline primary education & -0.438 & $(5.00)$ & -0.437 & $(4.99)$ & -0.436( & $(4.99)$ & -0.438 & $(5.00)$ \\
\hline higher education & 0.4051 & $(3.17)$ & 0.405 & $(3.17)$ & 0.4051 & $(3.17)$ & 0.438 & $(3.41)$ \\
\hline children & $-0.965 \mid$ & $(9.52)$ & -0.970 & $(9.58)$ & -0.970 & $(9.58)$ & -0.991 & $(9.74)$ \\
\hline $\begin{array}{l}\text { not head of } \\
\text { hougehold single } \\
\text { (nhhs) }\end{array}$ & $-1.277(1$ & 11.581 & $-1.263(1$ & $11.46)$ & $-1.263(1$ & $11.46)$ & $-1.329(1$ & $(11.75)$ \\
\hline $\begin{array}{l}\operatorname{married} \text { with working } \\
\text { wife }\end{array}$ & $-0.662 i$ & $(5.02)$ & -0.663 & $(5.03)$ & -0.663 & $(5.03)$ & -0.654 & $(4.95)$ \\
\hline unemployed & 0.0401 & $(0.19)$ & 0.631 & $(2.98)$ & 0.6311 & $(2.98)$ & 0.625 & $(2.94)$ \\
\hline registered at INEM & & -- & -1.503 & $(6.29)$ & -1.499 ( & $(6.25)$ & -1.501 & $(6.03)$ \\
\hline tenure $\geq 3$ years & $-0.972 \mid$ & $(9.89)$ & -0.979 & $(9.94)$ & -0.978 & $(9.94)$ & -0.971( & $(9.85)$ \\
\hline $\begin{array}{l}\text { employee in public } \\
\text { gector }\end{array}$ & 1.418( & $(8.31)$ & 1.417 & $(8.33)$ & 1.416( & $(8.33)$ & 1.408 & $(8.25)$ \\
\hline $\begin{array}{l}\text { employee in private } \\
\text { Bector }\end{array}$ & 0.9631 & $(6.15)$ & 0.964( & $(6.18)$ & 0.9641 & $(6.18)$ & 0.960 & $(6.14)$ \\
\hline agriculture & -0.665( & $(3.09)$ & -0.6731 & $(3.13)$ & $-0.674 i$ & $(3.13)$ & -0.671 & $(3.11)$ \\
\hline industry & -0.931 & $(6.22)$ & -0.928 & $(6.20)$ & -0.928( & $(6.20)$ & -0.930 & $(6.21)$ \\
\hline services & -0.235( & $(1.93)$ & -0.232 & $(1.91)$ & -0.232 & $(1.91)$ & -0.232 & $(1.91)$ \\
\hline $\begin{array}{l}\text { Unemploywent } \\
\text { differential }\end{array}$ & -4.303 & $(4.98)$ & -4.029 & $(4.66)$ & -3.966 & $(4.20)$ & -0.084 & $(0.06)$ \\
\hline Unempl diff & & -- & & -- & -0.351 & $(0.16)$ & 4.3341 & $(1.80)$ \\
\hline registered & & -- & & -- & & -- & -14.079 & $(2.87)$ \\
\hline * higher education & & -- & & -- & & -- & 3.686 & $(1.42)$ \\
\hline * children & & -- & & -- & & -- & -5.468 & $(2.83)$ \\
\hline * nhiss & & -- & & -- & & -- & -9.360 & $(4.32)$ \\
\hline $\begin{array}{l}\text { Partlcigation rate } \\
\text { growth differential }\end{array}$ & 0.110 & $(4.34)$ & 0.109 & $(4.33)$ & 0.109 & $(4.33)$ & 0.122 & $(4.50)$ \\
\hline $\begin{array}{l}\text { Partic rate growth } \\
\text { diff. higher } \\
\text { education }\end{array}$ & & - & & -- & & -- & -0.101 & $(1.38)$ \\
\hline $\begin{array}{l}\text { Rouseprice } \\
\text { differential }\end{array}$ & 0.933 & $(4.69)$ & 0.904 & $(4.55)$ & 0.904 & $(4.54)$ & 0.921 & $(4.64)$ \\
\hline $\begin{array}{l}\text { house price } \\
\text { differentlal| }\end{array}$ & & -- & & -- & & -- & & -- \\
\hline $\begin{array}{l}\text { Aleal wage } \\
\text { differential }\end{array}$ & 2.115 & $(4.84)$ & 2.149 & $(4.92)$ & 2.149 & $(4.92)$ & 2.170 & $(4.96)$ \\
\hline $\begin{array}{l}\text { Aesociation of } \\
\text { predicted prob. } \\
\text { end obnerved } \\
\text { regponses }\end{array}$ & & & & & & & & \\
\hline concordant & & 71.58 & & 72.68 & & 72.68 & & 72.78 \\
\hline tied & & 15.38 & & 14.68 & & 14.68 & & 14.68 \\
\hline - log likelihood & & 032.44 & & 008.44 & & 008.43 & & 992.15 \\
\hline
\end{tabular}

Notes: As for table 2 . 


\section{REFERENCES}

DA VANZO, J. (1978): "Does Unemployment Affect Migration? Evidence from Microdata", Review of Economics and Statistics, November, 504-514.

GABRIEL, S.A., SHACK-MARQUEZ, J. and W.L. WESCHER (1992): "Regional House-Price Dispersion and Interregional Migration", Journal of Housing Economics, vol. 2, 235-256.

GREENWOOD, M.J. (1975): "Research on Internal Migration in the United States: A Survey, Journal of Economic Literature, June, 397-433.

" (1985): "Human Migration: Theory, Models, and Empirical Studies", Journal of Regional Science, vol. 25, nㅇ 4, 521-544.

KLEIN, R.W. and R.H. SPADY (1993): "An Efficient Semiparametric Estimator for Binary Response Models", Econometrica, March, vol. 61, no $2,387-422$.

MINCER, J. (1978): "Family Migration Decisions", Journal of Political Economy, vol. 86, no 5, 749-773.

OLANO REY, A. (1990): "Las Migraciones Interiores en Fase de Dispersión", Revista de Economia y Sociología del Trabajo, septiembre, 86-98.

PISSARIDES, C.A. and J. WADSWORTH (1989): "Unemployment and the Inter-Regional Mobility of Labour", The Economic Journal, September, 739-755.

ROBACK, J. (1982): "Wages, Rents, and the Quality of Life", Journal of Political Economy, December, 1257-1278.

VUONG, Q.M. (1989): "Likelihood Ratio Tests for Model Selection and Non-Nested Hypotheses", Econometrica, March, 307-333. 


\section{WORKING PAPERS (1)}

9201 Pedro Martinez Méndez: Tipos de interés, impuestos e inflación.

9202 Víctor García-Vaquero: Los fondos de inversión en España.

9203 César Alonso and Samuel Bentolila: The relationship between investment and tobin's Q in Spanish industrial finns. (The Spanish original of this publication has the same number.)

9204 Cristina Mazón: Márgenes de beneficio, eficiencia y poder de mercado en las empresas españolas.

9205 Cristina Mazón: El margen precio-coste marginal en la encuesta industrial: 1978-1988.

9206 Fernando Restoy: Intertemporal substitution, risk aversion and short term interest rates.

9207 Fernando Restoy: Optimal porffolio policies under time-dependent retums.

9208 Fernando Restoy and Georg Michael Rockinger: Investunent incentives in endogenously growing economies.

9209 José M. González-Páramo, José M. Roldán y Miguel Sebastián: Cuestiones sobre política fiscal en España.

9210 Ángel Serrat Tubert: Riesgo, especulación y cobertura en un mercado de fururos dinámico.

9211 Soledad Núñez Ramos: Fras, futuros y opciones sobre el MIBOR.

9212 Federico J. Sáez: El funcionamiento del mercado de deuda pública anotada en España.

9213 Javier Santillán: La idoneidad y asignación del ahorro mundial.

9214 María de los Llanos Matea: Contrastes de raíces unitarias para series mensuales. Una aplicación al IPC.

9215 Isabel Argimón, José Manuel González-Páramo y José María Roldán: Ahorro, riqueza y tipos de interés en España.

9216 Javier Azcárate Aguilar-Amat: La supervisión de los conglomerados financieros.

9217 Olympia Bover: An empirical model of house prices in Spain (1976-1991). (The Spanish original of this publication has the same number.)

9218 Jeroen J. M. Kremers, Neil R. Ericsson and Juan J. Dolado: The power of cointegration tests.

9219 Luis Julián Álvarez, Juan Carlos Delrieu and Javier Jareño: Treatment of conflictive forecasts: Efficient use of non-sample information. (The Spanish original of this publication has the same number.)

9220 Fernando C. Ballabriga y Miguel Sebastián: Déficit público y tipos de interés en la economía española: ¿existe evidencia de causalidad?

9221 Fernando Restoy: Interest rates and fiscal discipline in monetary unions. (The Spanish original of this publication has the same number.)

9222 Manuel Arellano: Introducción al análisis econométrico con datos de panel.

9223 Ángel Serrat: Diferenciales de tipos de interés onshore/off shore y operaciones swap.

9224 Ángel Serrat: Credibilidad y arbitraje de la peseta en el SME.

9225 Juan Ayuso and Fernando Restoy: Efficiency and risk premia in foreign exchange markets. (The Spanish original of this publication has the same number.)

9226 Luis J. Álvarez, Juan C. Delrieu y Antoni Espasa: Aproximación lineal por tramos a comportamientos no lineales: estimación de señales de nivel y crecimiento.

9227 Ignacio Hernando y Javier Vallés: Productividad, estructura de mercado y situación financiera.

9228 Ángel Estrada García: Una función de consumo de bienes duraderos.

9229 Juan J. Dolado and Samuel Bentolila: Who are the insiders? Wage setting in spanish manufacturing firms.

9301 Emiliano González Mota: Políticas de estabilización y límites a la autonomía fiscal en un área monetaria y económica común.

9302 Anindya Baner jee, Juan J. Dolado and Ricardo Mestre: On some simple tests for cointegration: the cost of simplicity.

9303 Juan Ayuso and Juan Xuis Vega: Weighted monetary aggregates: The Spanish case. (The Spanish original of this publication has the same number.)

9304 Ángel Luis Gómez Jiménez: Indicadores de la política fiscal: una aplicación al caso español.

9305 Ángel Estrada y Miguel Sebastián: Una serie de gasto en bienes de consumo duradero. 
9306 Jesús Briones, Ängel Estrada e Ignacio Hernando: Evaluación de los efectos de reformas en la imposición indirecta

9307 Juan Ayuso, María Pérez Jurado y Fernando Restoy: Indicadores de credibilidad de un régimen cambiario: el caso de la peseta en el SME.

9308 Cristina Mazón: Regularidades empíricas de las empresas industriales españolas: ¿existe correlación entre beneficios y participación?

9309 Juan Dolado, Alessandra Goria and Andrea Ichino: Immigration and growth in the host country.

9310 Amparo Ricardo Ricardo: Series históricas de contabilidad nacional y mercado de trabajo para la CE y EEUU: 1960-1991.

9311 Fernando Restoy and G. Michael Rockinger: On stock market returns and returns on investment.

9312 Jesús Saurina Salas: Indicadores de solvencia bancaria y contabilidad a valor de mercado.

9313 Isabel Argimón, José Manuel González-Páramo, María Jesús Martín y José María Roldán: Productividad e infraestructuras en la economía española.

9314 Fernando Ballabriga, Miguel Sebastián and Javier Vallés: Interdependence of EC economies: A VAR approach.

9315 Isabel Argimón y M. Jesús Martín: Series de «stock» de infraestructuras del Estado y de las Administraciones Públicas en España.

9316 P. Martínez Méndez: Fiscalidad, tipos de interés y tipo de cambio.

9317 P. Martinez Méndez: Efectos sobre la política económica española de una fiscalidad distorsionada por la inflación.

9318 Pablo Antolín and Olympia Bover: Regional Migration in Spain: The effect of Personal Characteristics and of Unemployment, Wage and House Price Differentials Using Pooled Cross-Sections

(1) Working Papers prior to 1992 are listed in Banco de España's publications catalogue.

Queries should be addressed to: Banco de España

Sección de Publicaciones. Negociado de Distribución y Gestión

Teléfono: 3385180

Alcalá, 50. 28014 Madrid 